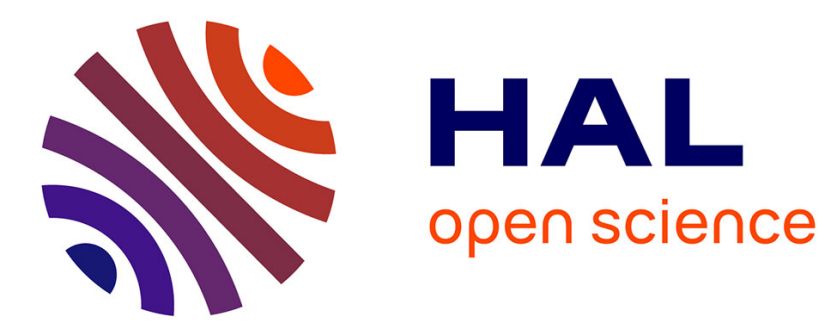

\title{
Quality of life after hemifacial spasm surgery: French versions of the HFS-8 and HFS-30 questionnaires
}

\author{
Lauranne Alciato, François Simon, Rémi Hervochon, Stéphanie Trunet, \\ Aurélien Nouet, Frédéric Tankéré
}

\section{- To cite this version:}

Lauranne Alciato, François Simon, Rémi Hervochon, Stéphanie Trunet, Aurélien Nouet, et al.. Quality of life after hemifacial spasm surgery: French versions of the HFS-8 and HFS-30 questionnaires. European Annals of Otorhinolaryngology, Head and Neck Diseases, 2021, 10.1016/j.anorl.2021.03.006 . hal-03283902

\section{HAL Id: hal-03283902 \\ https://hal.sorbonne-universite.fr/hal-03283902}

Submitted on 12 Jul 2021

HAL is a multi-disciplinary open access archive for the deposit and dissemination of scientific research documents, whether they are published or not. The documents may come from teaching and research institutions in France or abroad, or from public or private research centers.
L'archive ouverte pluridisciplinaire HAL, est destinée au dépôt et à la diffusion de documents scientifiques de niveau recherche, publiés ou non, émanant des établissements d'enseignement et de recherche français ou étrangers, des laboratoires publics ou privés. 
Quality of life after hemifacial spasm surgery: French versions of the HFS-8 and HFS30 questionnaires

Lauranne Alciato ${ }^{*}$, François Simon $^{2}$, Rémi Hervochon ${ }^{1}$, Stéphanie Trunet ${ }^{3}$, Aurélien Nouet ${ }^{4}$, Frédéric Tankéré ${ }^{1}$

${ }^{1}$ Sorbonne Université, AP-HP, GHU Pitié-Salpêtrière, DMU ChIR, Service d'Oto-Rhino-Laryngologie, GRC Robotique et Innovation Chirurgicale, Paris, France

${ }^{2}$ Université de Paris, AP-HP, Hôpital Necker-Enfants Malades, Service d'Oto-Rhino-Laryngologie, Paris, France

${ }^{3}$ AP-HP, GHU Pitié-Salpêtrière, Service de Neuroradiologie, Paris, France

${ }^{4}$ AP-HP, GHU Pitié-Salpêtrière, DMU ChIR, Service de Neurochirurgie, Paris, France

\section{*Corresponding author:}

E-mail: lauranne.alciato@gmail.com (Lauranne Alciato)

Telephone: +33 (0)611351777 


\begin{abstract}
Objectives. The aim of the present study was to assess quality of life before and after surgery for hemifacial spasm, in order to validate two specific quality of life scales translated in French. Surgical results and complications were reported. Material and methods. Twenty-three patients with hemifacial spasm treated by microvascular decompression were retrospectively included. The HFS-8 and HFS30 quality of life scales were translated from English into French using a forwardbackward method and implemented on patients at least 1 year after surgery. Results. Median HFS-8 and HFS-30 values were respectively $16 \pm 12.5$ (range, 8 -20.5 ) and $38 \pm 38.5$ (range, $23-61.5$ ) before surgery and $0.5 \pm 4.5$ (range, $0-$ 4.5) and $5 \pm 17.5$ (range, $1-18.5$ ) after surgery, showing significant improvement in quality of life $(\mathrm{p}<0.001)$. The internal consistency of both scales was excellent (Cronbach's alpha $>0.9$ ), and they were significantly correlated (Pearson coefficient $=0.95 ; 95 \%$ CI $[0.91 ; 0.98] ; \mathrm{p}<0.0001)$. Success rates were respectively $83 \%$ and $91 \%$ after primary and revision surgeries. Complications were transient with minor consequences in $80 \%$ of cases, but could impact quality of life when lasting. Conclusions. These results support the validity of the French versions of HFS-8 and HFS-30. Microvascular decompression is a safe and effective treatment for hemifacial spasm, and these scales are reliable tools to assess postoperative quality of life.
\end{abstract}

Key-words: microvascular decompression; cerebellopontine angle; facial nerve; quality of life scale; translation. 


\section{Introduction}

Primary hemifacial spasm consists in involuntary tonic and/or clonic muscle contractions on one side of the face [1]. Etiology involves vascular compression at the emergence of the facial nerve from the brainstem in the cerebellopontine angle [2,3]. Although not life-threatening, it is functionally bothersome and, in severe cases, can impair vision and speech. Patients complain, however, less of the physical problems than of social issues, both personal and occupational, which may lead to anxiety and depression [4]. Microvascular decompression is presently the sole curative treatment, definitively resolving spasm with a low risk of complications $[2,3,5-7]$.

Although many studies have reported surgical results and morbidity following microvascular decompression for hemifacial spasm $[5,6]$, few assessed quality of life, which may not correlate with improvement in terms of spasm and needs to be taken into account in assessing success [8,9]. Some English-language articles used a standardized scale [7,8,10-13], but there have previously been no French versions, limiting French assessments of microvascular decompression.

The main aim of the present study was to assess quality of life before and after microvascular decompression, by developing French versions of the two most widely used hemifacial spasm quality of life questionnaires: Hemifacial Spasm 8 (HFS-8) and 30 (HFS-30) [7,8,10-15]. Secondary objectives were to correlate intraoperative findings and surgical results, in terms of success and morbidity, with quality of life.

\section{Material and Methods}

A single-center retrospective study was conducted in patients undergoing microvascular decompression for hemifacial spasm between October 2013 and September 2019 in a university hospital. The CNP ORL ethical review board approved the study $\left(\mathrm{n}^{\circ} 2020-05-002-\mathrm{SP}\right)$.

Inclusion criteria comprised age $>18$ years, hemifacial spasm confirmed clinically and on EMG and MRI, primary microvascular decompression performed by the same team of otologic and neurologic surgeons using the technique described below, and patient consent. Exclusion criteria comprised secondary hemifacial 
spasm, inability to respond to the questionnaires, and loss to follow-up. Patient data were collected from medical files in an anonymized Excel file and are shown in Table 1. Twenty-three patients were included: 13 female (57\%) 10 male (43\%); mean age at symptom onset and at surgery, respectively $49 \pm 11$ years (range, $28-$ 70 years) and $56 \pm 11$ years (range, $36-76$ years). Mean onset-to-surgery time was $84 \pm 58$ months (range, $4-200$ months). Mean follow-up was $29 \pm 17$ months (range, 12 - 66 months). Patients were mainly classified as racially caucasian $(\mathrm{n}=18,78 \%)$, with 5 born in Asia (22\%). Preoperatively, 17 patients (74\%) had received botulinum toxin injection, discontinued for poor efficacy, loss of efficacy or adverse events. The other 6 patients $(26 \%)$ requested surgery in first line. EMG showed typical spasm signs (hypertonia at rest, myokymia, blink reflex diffusion) and MRI systematically found neurovascular impingement.

Two specific quality of life questionnaires were used: HFS-8 and HFS-30. HFS-30 comprises 30 items in 7 domains [14]: mobility, activities of daily living, emotional well-being, stigma, social support, cognition, and communication. Items were scored on a 5 -point scale: $0=$ never, $1=$ rarely, $2=$ sometimes, $3=$ often, $4=$ always. The HFS-8 is a short-form version of the HFS-30, comprising the 7 most sensitive items plus a question on sleep quality [7,8,10-13,15]. Scoring is as follows: 0 = normal; 1 = slight disability; 2 = moderate disability, no functional impairment; 3 = moderate disability, functional impairment; $4=$ severely incapacitated. Maximal scores (HFS-30: 120; HFS-8: 32) indicate maximal impairment of quality of life, and low scores indicate good quality of life. The English versions were translated into French, using the "forward-backward" translation method [16], by 2 French otorhinolaryngologist specialists with a good level in English and 1 native American English teacher. The French and original English versions are shown in Appendices 1a, b and 2a, b. Patients filled out both: first retrospectively, assessing preoperative quality of life, and secondly assessing present quality of life at a minimum 1 year after surgery $[7,8,10-13]$. Pre- and postoperative scores were compared, to assess improvement. Internal consistency (i.e., degree of correlation between items of a given questionnaire) and external consistency (i.e., degree of correlation between the two questionnaires) were calculated to assess the reliability of the translations [16]. 
Intraoperative findings were collected from operative reports: causal vessel(s), quality of endoscopic control, operative time, and hospital stay. Surgery was performed under general anesthesia, with the patient in supine position, head turned to the contralateral side on a U-shaped headrest. Facial nerve monitoring $\left(\mathrm{NIM}^{\circledR}\right.$, Medtronic, Jacksonville, FL, USA) and cochlear nerve monitoring by

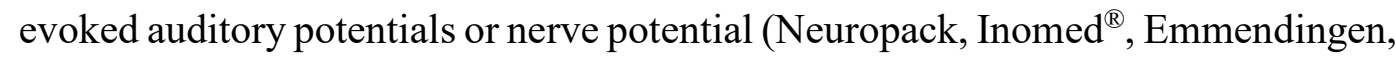
Germany) were performed. The posterior fossa dura was exposed by retrosigmoid craniectomy. After opening the dura, the cerebellomedullary cistern and the cerebellopontine angle cisterns, the lower cranial nerves were first located then, the acousticofacial bundle and trigeminal nerve. Endoscopy was systematically performed to analyze the neurovascular impingement and determine the causal vessel(s). Decompression was then performed under microscopy, by dissecting causal vessel(s) and interposing one or more Teflon fragments to isolate the facial nerve from any neighboring vascular structures (Figure 1). Postoperatively, spasm regression was assessed by the surgeon as: immediate complete resolution (during hospitalization), delayed complete resolution (within weeks or months), or persistence (counted as failure). Data for postoperative complications, recurrence and surgical revision were collected.

Statistical analyses used Microsoft Excel version 16.35 and GraphPad Prism version 8.4.0, for MacOS. Continuous variables were reported as mean \pm standard deviation (range), noncontinuous variables as median with $1^{\text {st }}-3^{\text {rd }}$ interquartile range, and categoric variables as number and percentage. As questionnaire response distributions were non-normal on Kolmogorov-Smirnov test, pre- to post-operative median scores were compared using non-parametric matched Wilcoxon test. The significance threshold was set at $\mathrm{p}<0.005$ with $\mathrm{p}$-values between 0.005 and 0.05 considered suggestive $[17,18]$. Internal consistency was assessed using Cronbach alpha with 95\% confidence interval; alpha 0.6-0.7 was considered acceptable, 0.70.9 good, and $>0.9$ excellent. External consistency was assessed using Pearson correlation coefficient with $95 \%$ confidence interval. Significant differences in spasm side according to causal vessel were assessed on chi $^{2}$ test. Probability of recovery after primary surgery was assessed on Kaplan-Meier estimation.

\section{Results}

Quality of life questionnaires 
Nineteen patients (83\%) responded to both questionnaires. Results are shown in Table 2.

Total HSF-8 score fell from $16 \pm 12.5$ (range, $8-20.5$ ) to $0.5 \pm 4.5$ (range, 0 - 4.5): i.e., a significant improvement after surgery $(\mathrm{p}<0.001)$. The item with the highest (poorest) preoperative value and greatest improvement was "Felt embarrassed about having the condition": $4 \pm 2$ (range, $2-4$ ) preoperatively versus $0 \pm 0.5(0-0.5)$ postoperatively $(\mathrm{p}<0.001)$. Internal consistency was excellent: alpha, 0.94 (95\% CI, [0.91;0.97]).

Total HSF-30 score fell from $38 \pm 38.5$ (range, $23-61.5$ ) to $5 \pm 17.5$ (range, $1-18.5)$ : i.e., a significant improvement after surgery $(p<0.001)$. The items with the highest preoperative value and greatest improvement were in the "Emotional well-being", and "Stigma" domains $(\mathrm{p}<0.001)$. Internal consistency was excellent: alpha, 0.96 (95\% CI, [0.94;0.97]).

The two scores showed significant correlation: Pearson $r=0.95$ (95\% CI, $[0.91 ; 0.98]) ; \mathrm{p}<0.0001$.

Regarding HFS-8 and HFS-30, respectively 16 (84\%) and 17 patients (90\%) showed improvement (Table 1). Two patients (11\%) with persistent spasm showed non-improvement on HFS-8 (\#7 and \#18), and 1 patient (5\%) on HFS-30 (\#7). One patient (5\%) with complete resolution of spasm showed aggravation on both scores (\#15).

\section{Intraoperative findings}

Involvement was left-sided in 17 cases (74\%). Facial nerve impingement implicated a single vessel in 13 cases (57\%) and several in 10 (43\%), including 2 cases $(9 \%)$ of triple impingement involving the posteroinferior cerebellar artery (PICA), anteroinferior cerebellar artery (AICA) and vertebral artery (VA). Table 3 shows results according to vessel involvement. Impingement seemed to involve multiple vessels on the left $(p<0.05)$ and the AICA on the right $(p<0.05)$. In the 2 patients with associated trigeminal neuralgia, there was impingement between the trigeminal nerve and the VA in 1 case and between the trigeminal nerve and a vein in the other. 
Endoscopic control provided precise visualization of the neurovascular impingement, except in 1 case where it was not possible to expose the emergence of the facial nerve for anatomic reasons (short acousticofacial bundle masked by the flocculus, with deep PICA imprint onto the brainstem) and because of unreasonable functional risk (impaired cochlear nerve potential, bradycardia secondary to manipulating the lower facial nerves); dissection was therefore halted and the impingement was not finally released.

Mean surgery time was $87 \pm 29$ minutes (range, $60-180 \mathrm{~min}$ ). Mean hospital stay was $7 \pm 1$ days (range, $5-9$ days).

\section{$\underline{\text { Postoperative complications }}$}

Ten patients (43\%) experienced one or more postoperative complications, which were transient in $80 \%$ of cases (Table 1). Transient complications comprised: 1 late House-Brackmann grade III facial palsy (4\%) at day 10, with full recovery within 3 months; 3 cases of sensorineural hearing loss (13\%); 1 of tinnitus (4\%); 4 of dizziness (17\%); 2 of healing defect ( $9 \%)$; and 2 of cerebrospinal fluid leak $(9 \%)$, managed medically. Lasting complications comprised: 1 case of total deafness with vestibular syndrome (4\%); and 1 vestibular syndrome lasting over 1 year $(4 \%)$. There were no severe complications such as definitive facial palsy, lower cranial nerves involvement, meningitis, intracranial bleeding, or death.

\section{$\underline{\text { Results concerning spasm }}$}

After primary surgery, in 11 patients (48\%) there was immediate complete resolution of spasm, and in $6(26 \%)$ delayed complete resolution at a mean time of $6 \pm 5$ months (range, 2 weeks to 13 months). Two patients (9\%) showed partial resolution, and $4(17 \%)$ had persistent spasm (including the case in which impingement could not be released). In case of complete resolution $(n=17)$, the success rate after primary surgery was $74 \%$; including partial resolution $(n=19)$, the success rate was $83 \%$. Probability of complete resolution was $57 \%$ (95\% CI, [0.38 ; $0.77])$ at 1 month, $61 \%(95 \% \mathrm{CI},[0.42 ; 0.80])$ at 6 months, and $70 \%(95 \% \mathrm{CI}$, $[0.53 ; 0.88]$ ) at 1 year (Figure 2). Median time to recovery was 15 days. 
Two patients with persistent spasm at 1 year underwent revision surgery, providing immediate complete resolution. Causes of failure of primary surgery comprised: impingement with a supernumerary branch not seen on primary surgery in 1 case, and Teflon fragment migration in the other. The success rate after revision surgery was $83 \%$ counting complete resolution $(n=19)$ and $91 \%$ including partial resolution $(n=21)$. There were no cases of recurrence at last follow-up.

In the 2 patients with initial signs of associated trigeminal nerve involvement, surgery resolved all symptoms.

\section{Discussion}

Quality of life is an important factor in the assessment of the impact of a disease and of treatment, especially in functional surgery such as microvascular decompression. It is now an important criterion to assess the success of hemifacial spasm treatment, and a standardized instrument has become essential [14,15]. The present study is the first to present French translations of the specific HFS-8 and HFS-30 questionnaires, often used in the English-language literature to assess postoperative quality of life in hemifacial spasm [7,8,10-13]. The present results confirmed that microvascular decompression is safe and effective [5-7], improving quality of life $[7,8,10-13]$.

In the HFS-30 questionnaire, the most sensitive items belonged to the "Emotional well-being" and "Stigma" domains, as in other reports of treatment by botulinum toxin [14] or surgery [13]. In the HFS-8 questionnaire, the item with greatest impact was "Felt embarrassed about having the condition", as previously reported in several studies of microvascular decompression $[7,8,10]$. These findings highlight the importance of the social and psychological aspects of hemifacial spasm. In the present series, 1 patient showing complete resolution of spasm reported aggravated quality of life (\#15), and another only moderate improvement (\#1), due to prolonged postoperative dizziness. Onset of complications, notably with long-term impact, accounts for this finding, reinforcing the idea that assessment of success must include assessment of quality of life [8,9]; thus, it seems important to use a specific quality of life questionnaire with patients undergoing microvascular decompression. Several HFS-30 items showed no significant improvement, and were thus non-contributive to quality of life assessment; the 
HFS-8 seemed sufficient and, being short and concise, offers a good tool in the surgical context. The almost perfect correlation between the two scores provides a further rationale for using the shorter one in clinical practice. Preoperative quality of life assessment could guide surgical decision-making in patients hesitating between medical and surgical treatment.

The present success rate was $83 \%$ for primary surgery and $91 \%$ including revision. Complications were mostly transient and not severe; these results match the literature and confirm the safety and efficacy of microvascular decompression $[5,7,11]$. Resolution of spasm may be delayed, in $20-50 \%$ of cases depending on the series $[5,7,11,19,20]$, but usually comes within 6 months and rarely later than 12 months $[7,19]$. In the present study, the mean interval was 6 months and the maximum 13. It thus seems reasonable to wait for at least a year before considering revision surgery. Causes of failure in the literature were similar to those in the present series [11]: failure to release the impinging artery, other vessel causing impingement, or migration of decompression material.

There was 1 case of late facial palsy. This was reported in several studies but the pathophysiology is controversial: vasospasm due to intraoperative manipulation or to the presence of Teflon, or else viral reactivation. Recovery is usually spontaneous within months, and this does not seem to jeopardize the prognosis for resolution of spasm [20].

Involvement was most often left-sided, with impingement by multiple vessels or the PICA in most cases. This left-side predominance has already been reported, but with no pathophysiological hypothesis [10,13-15]. However, an association between left-side involvement and impingement by multiple vessels or the PICA has previously been reported [21], and may account for the present predominance findings.

The present study had several limitations. 1) The retrospective design incurred methodological bias, especially for assessment of preoperative quality of life. However, hemifacial spasm had a strong impact on the patients' life, and their memory of the condition seemed to be precise. The method had been used in other studies of quality of life after microvascular decompression, and enabled the questionnaires to be validated $[7,8,10-12]$. A single recent study reported prospective data using the HFS-30 questionnaire after microvascular 
decompression, and confirmed improvement in quality of life [13]. 2) We were not able to assess the reproducibility of our questionnaires, which we implemented once only. 3) The series was small, and the results should be seen as preliminary. Given the low incidence of this pathology $(<0.01 \%)$ [22], a multicenter prospective study using these validated French-language questionnaires with repeated administration would overcome the present study limitations and could confirm the results. The questionnaires could then be routinely used to follow up quality of life in patients managed medically and surgically, so as best to adapt treatment.

\section{Conclusion}

Microvascular decompression is an effective treatment in hemifacial spasm, improving quality of life. Complications are mostly transient but, when lasting, may impact the patient's experience. Quality of life monitoring using specific questionnaires such as the HFS-8 or HFS-30 in French versions is essential for assessing this functional surgery, providing objective evidence of satisfaction.

\section{Disclosure of interest}

The authors have no conflicts of interest to disclose.

\section{Acknowledgments}

The authors thank Ms Pamela Combastet for help with translating the questionnaires, and all of the patients who consented to be involved in their development. 


\section{References}

[1] Wang A, Jankovic J. Hemifacial spasm: clinical findings and treatment. Muscle Nerve Off J Am Assoc Electrodiagn Med 1998;21:1740-1747.

[2] Jannetta PJ, Abbasy M, Maroon JC, Ramos FM, Albin MS. Etiology and definitive microsurgical treatment of hemifacial spasm. Operative techniques and results in 47 patients. J Neurosurg 1977;47:321-8.

[3] Gardner WJ, Sava GA. Hemifacial spasm — a reversible pathophysiologic state. J Neurosurg 1962;19:240-247.

[4] Tan E-K, Lum S-Y, Fook-Chong S, Chan L-L, Gabriel C, Lim L. Behind the facial twitch: depressive symptoms in hemifacial spasm. Parkinsonism Relat Disord 2005;11:241-5.

[5] Miller LE, Miller VM. Safety and effectiveness of microvascular decompression for treatment of hemifacial spasm: a systematic review. Br J Neurosurg 2012;26:438-44.

[6] McLaughlin MR, Jannetta PJ, Clyde BL, Subach BR, Comey CH, Resnick DK.

Microvascular decompression of cranial nerves: lessons learned after 4400 operations. J

Neurosurg 1999;90:1-8.

[7] Lawrence JD, Frederickson AM, Chang Y-F, Weiss PM, Gerszten PC, Sekula RF. An investigation into quality of life improvement in patients undergoing microvascular decompression for hemifacial spasm. J Neurosurg 2018;128:193-201.

[8] Heuser K, Kerty E, Eide PK, Cvancarova M, Dietrichs E. Microvascular decompression for hemifacial spasm: postoperative neurologic follow-up and evaluation of life quality. Eur J Neurol 2007;14:335-40.

[9] Reimer J, Gilg K, Karow A, Esser J, Franke GH. Health-related quality of life in blepharospasm or hemifacial spasm. Acta Neurol Scand 2005;111:64-70.

[10] Ray DK, Bahgat D, McCartney S, Burchiel KJ. Surgical Outcome and Improvement in Quality of Life after Microvascular Decompression for Hemifacial Spasms: A Case Series Assessment Using a Validated Disease-Specific Scale. Stereotact Funct Neurosurg 2010;88:383-9.

[11] Montava M, Rossi V, Fais CC, Mancini J, Lavieille J-P. Long-term surgical results in microvascular decompression for hemifacial spasm: efficacy, morbidity and quality of life.

Acta Otorhinolaryngol Ital 2016;36:220.

[12] Sandel T, Eide PK. Long-term results of microvascular decompression for trigeminal neuralgia and hemifacial spasms according to preoperative symptomatology. Acta Neurochir (Wien) 2013;155:1681-92.

[13] Cheng J, Lei D, Hui X, Zhang H. Improvement of Quality of Life in Patients with Hemifacial Spasm After Microvascular Decompression: A Prospective Study. World Neurosurg 2017;107:549-53.

[14] Tan E-K, Fook-Chong S, Lum S-Y, Lim E. Botulinum toxin improves quality of life in hemifacial spasm: validation of a questionnaire (HFS-30). J Neurol Sci 2004;219:151-5.

[15] Tan EK, Fook-Chong S, Lum S-Y, Thumboo J. Validation of a short disease specific quality of life scale for hemifacial spasm: correlation with SF-36. J Neurol Neurosurg Psychiatry 2005;76:1707-10.

[16] Acquadro C, Conway K, Hareendran A, Aaronson N. Literature Review of Methods to Translate Health-Related Quality of Life Questionnaires for Use in Multinational Clinical

Trials. Value Health 2008;11:509-21.

[17] Ioannidis JPA. The Proposal to Lower P Value Thresholds to .005. JAMA 2018;319:1429-30.

[18] Laccourreye O, Lisan Q, Bonfils P, et al. Use of P-values and the terms "significant", "non-significant" and "suggestive" in Abstracts in the European Annals of

Otorhinolaryngology, Head \& Neck Diseases. Eur Ann Otorhinolaryngol Head Neck Dis 2019;136:469-73. 
[19] Ishikawa M, Nakanishi T, Takamiya Y, Namiki J. Delayed resolution of residual hemifacial spasm after microvascular decompression operations. Neurosurgery 2001;49:847856.

[20] Lee JM, Park HR, Choi YD, et al. Delayed facial palsy after microvascular decompression for hemifacial spasm: friend or foe? J Neurosurg 2018;129:299-307.

[21] Chung M, Han I, Chung S-S, Huh R. Side predilections of offending arteries in hemifacial spasm. J Clin Neurosci 2016;29:106-10.

[22] Chaudhry N, Srivastava A, Joshi L. Hemifacial spasm: The past, present and future. J Neurol Sci 2015;356:27-31. 


\begin{tabular}{|c|c|c|c|c|c|c|c|c|c|c|c|c|c|c|}
\hline & & & & Pro & & & & & Fol & & & & & \\
\hline & $\mathrm{G}$ & & & gre & and & & & Snasm & lo & & $\mathrm{H}$ & $\mathrm{H}$ & & $\mathrm{HF}$ \\
\hline $\mathrm{P}$ & en & A & $\mathrm{Si}$ & ssi & VIII & Botulinu & Vess & results of & W- & Complica & FS & FS & $\mathrm{S}_{-}$ & S- \\
\hline $\mathrm{t}$ & de & ge & de & on & nerve & $m$ toxin & els & primary & up & tions & -8 & -8 & 30 & 30 \\
\hline & $\mathrm{r}$ & & & $(\mathrm{m}$ & functi & & & surgery & $(\mathrm{m}$ & & $\mathrm{pr}$ & po & pre & pos \\
\hline & & & & ont & on & & & & ont & & $\mathrm{e}$ & st & & $\mathrm{t}$ \\
\hline & & & & hs) & & & & & hs) & & & & & \\
\hline
\end{tabular}

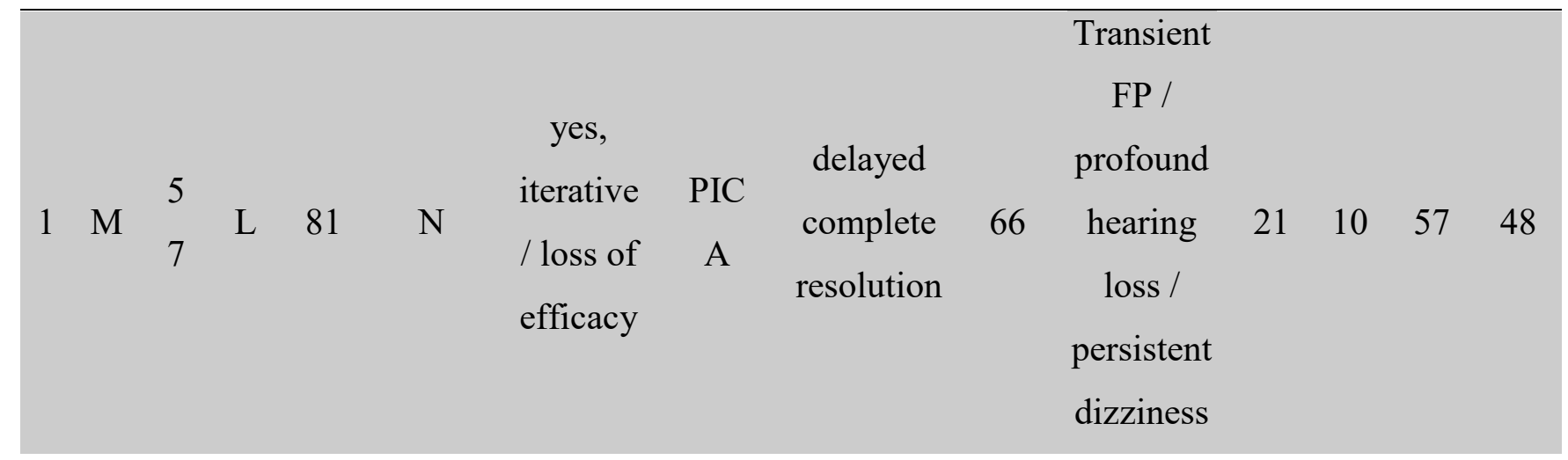

\section{V}

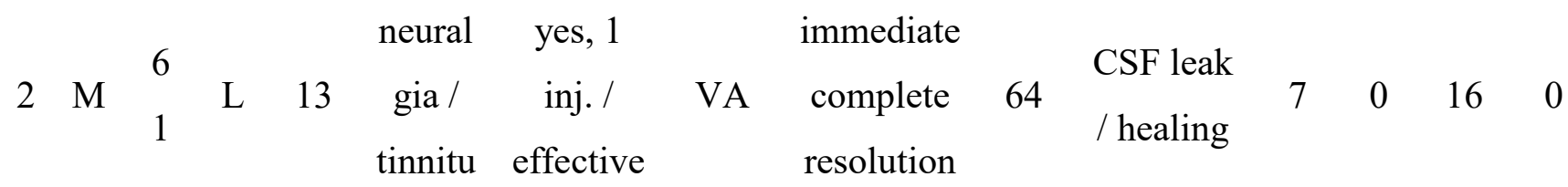
S

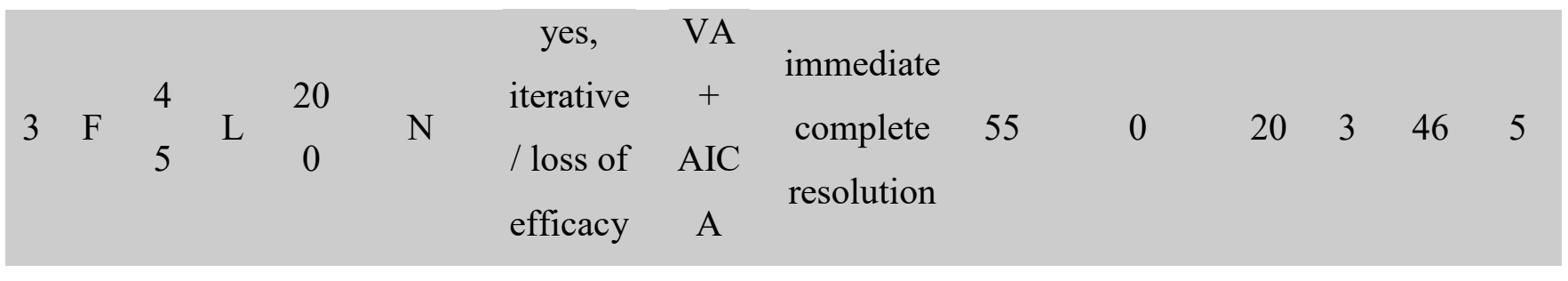
yes,

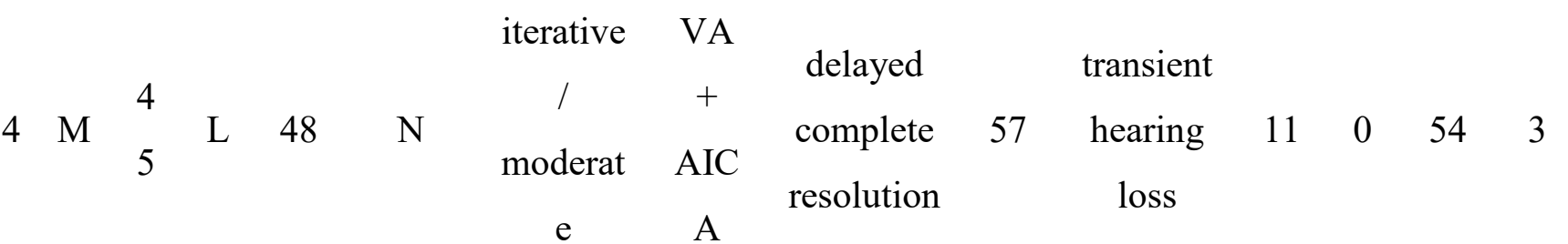
efficacy

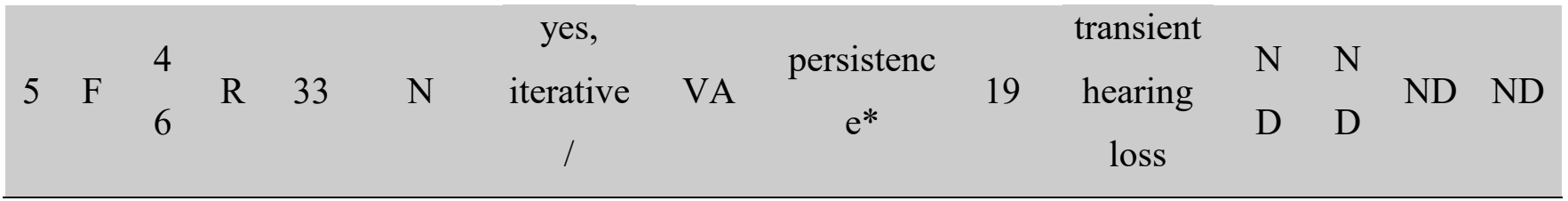




\begin{tabular}{|c|c|c|c|c|c|c|c|c|c|c|c|c|c|c|}
\hline & & & & & & $\begin{array}{l}\text { moderat } \\
\text { e } \\
\text { efficacy }\end{array}$ & & & & & & & & \\
\hline 6 & $\mathrm{M}$ & $\begin{array}{l}6 \\
3\end{array}$ & $\mathrm{~L}$ & $\begin{array}{c}18 \\
0\end{array}$ & $\begin{array}{c}\text { VII } \\
\text { deficit }\end{array}$ & no & $\begin{array}{c}\mathrm{PIC} \\
\mathrm{A}+ \\
\mathrm{AIC} \\
\mathrm{A}\end{array}$ & $\begin{array}{l}\text { immediate } \\
\text { complete } \\
\text { resolution }\end{array}$ & 39 & $\begin{array}{l}\text { transient } \\
\text { dizziness }\end{array}$ & 12 & 0 & 48 & 2 \\
\hline 7 & $\mathrm{~F}$ & $\begin{array}{l}3 \\
6\end{array}$ & $\mathrm{~L}$ & 75 & $\begin{array}{c}\text { VII } \\
\text { deficit }\end{array}$ & $\begin{array}{c}\text { yes, } \\
\text { iterative } \\
/ \\
\text { moderat } \\
\text { e } \\
\text { efficacy } \\
\text { / FP }\end{array}$ & $\begin{array}{c}\text { PIC } \\
\text { A }\end{array}$ & $\begin{array}{c}\text { persistenc } \\
\mathrm{e}^{*}\end{array}$ & 38 & 0 & 19 & 19 & 38 & 38 \\
\hline 8 & $\mathrm{~F}$ & $\begin{array}{l}5 \\
7\end{array}$ & $\mathrm{R}$ & 51 & $\mathrm{~N}$ & $\begin{array}{c}\text { yes, } \\
\text { iterative } \\
/ \\
\text { moderat } \\
\text { e } \\
\text { efficacy } \\
\text { / FP }\end{array}$ & $\begin{array}{c}\text { PIC } \\
\text { A }\end{array}$ & $\begin{array}{l}\text { delayed } \\
\text { complete } \\
\text { resolution }\end{array}$ & 36 & $\begin{array}{l}\text { tinnitus }+ \\
\text { transient } \\
\text { dizziness }\end{array}$ & 17 & 0 & 31 & 0 \\
\hline 9 & $\mathrm{~F}$ & $\begin{array}{l}4 \\
6\end{array}$ & $\mathrm{R}$ & 89 & $\mathrm{~N}$ & $\begin{array}{c}\text { yes, } \\
\text { iterative } \\
\text { moderat } \\
\text { e } \\
\text { efficacy }\end{array}$ & $\begin{array}{c}\text { AIC } \\
\text { A }\end{array}$ & $\begin{array}{l}\text { delayed } \\
\text { complete } \\
\text { resolution }\end{array}$ & 17 & 0 & $\begin{array}{l}\mathrm{N} \\
\mathrm{D}\end{array}$ & $\begin{array}{l}\mathrm{N} \\
\mathrm{D}\end{array}$ & ND & ND \\
\hline $\begin{array}{l}1 \\
0\end{array}$ & $\mathrm{~F}$ & $\begin{array}{l}5 \\
6\end{array}$ & $\mathrm{~L}$ & 44 & $\mathrm{~N}$ & $\begin{array}{c}\text { yes, } \\
\text { iterative } \\
/ \\
\text { moderat } \\
\text { e } \\
\text { efficacy }\end{array}$ & $\begin{array}{c}\text { PIC } \\
\text { A }\end{array}$ & $\begin{array}{c}\text { partial } \\
\text { resolution }\end{array}$ & 33 & 0 & 24 & 7 & 73 & 37 \\
\hline
\end{tabular}




\begin{tabular}{|c|c|c|c|c|c|c|c|c|c|c|c|c|c|c|}
\hline & & & & & & $\begin{array}{c}/ \\
\text { ecchym } \\
\text { osis }\end{array}$ & & & & & & & & \\
\hline $\begin{array}{l}1 \\
1\end{array}$ & F & $\begin{array}{l}4 \\
9\end{array}$ & $\mathrm{~L}$ & 46 & $\mathrm{~N}$ & $\begin{array}{c}\text { yes, } 2 \\
\text { inj. / } \\
\text { moderat } \\
\text { e } \\
\text { efficacy } \\
\text { / FP, } \\
\text { ptosis }\end{array}$ & $\begin{array}{c}\mathrm{PIC} \\
\mathrm{A}+\mathrm{V} \\
\mathrm{A}\end{array}$ & $\begin{array}{l}\text { immediate } \\
\text { complete } \\
\text { resolution }\end{array}$ & 28 & 0 & 32 & 0 & $\begin{array}{c}10 \\
3\end{array}$ & 5 \\
\hline $\begin{array}{l}1 \\
2\end{array}$ & $\mathrm{M}$ & $\begin{array}{l}5 \\
1\end{array}$ & $\mathrm{~L}$ & $\begin{array}{c}14 \\
5\end{array}$ & $\mathrm{~N}$ & $\begin{array}{c}\text { yes, } \\
\text { iterative } \\
\text { / loss of } \\
\text { efficacy }\end{array}$ & $\begin{array}{c}\mathrm{PIC} \\
\mathrm{A}\end{array}$ & $\begin{array}{l}\text { delayed } \\
\text { complete } \\
\text { resolution }\end{array}$ & 29 & 0 & 8 & 0 & 28 & 0 \\
\hline $\begin{array}{l}1 \\
3\end{array}$ & F & $\begin{array}{l}4 \\
3\end{array}$ & $\mathrm{R}$ & 15 & $\mathrm{~N}$ & no & $\begin{array}{c}\text { PIC } \\
\text { A }\end{array}$ & $\begin{array}{l}\text { immediate } \\
\text { complete } \\
\text { resolution }\end{array}$ & 24 & 0 & 15 & 0 & 23 & 0 \\
\hline $\begin{array}{l}1 \\
4\end{array}$ & F & $\begin{array}{l}6 \\
1\end{array}$ & $\mathrm{~L}$ & $\begin{array}{c}10 \\
1\end{array}$ & $\begin{array}{c}\mathrm{V} \\
\text { neural } \\
\text { gia }\end{array}$ & no & $\begin{array}{c}\mathrm{PIC} \\
\mathrm{A}+ \\
\mathrm{AIC} \\
\mathrm{A}\end{array}$ & $\begin{array}{l}\text { immediate } \\
\text { complete } \\
\text { resolution }\end{array}$ & 26 & 0 & 32 & 0 & 77 & 9 \\
\hline 5 & $\mathrm{M}$ & $\begin{array}{l}7 \\
2\end{array}$ & $\mathrm{~L}$ & 22 & $\mathrm{~N}$ & $\begin{array}{c}\text { yes, } 2 \\
\text { inj. / } \\
\text { moderat } \\
\text { e } \\
\text { efficacy } \\
\text { / FP }\end{array}$ & $\begin{array}{c}\text { PIC } \\
\mathrm{A}+ \\
\text { VA } \\
+ \\
\text { AIC } \\
\text { A }\end{array}$ & $\begin{array}{l}\text { immediate } \\
\text { complete } \\
\text { resolution }\end{array}$ & 17 & $\begin{array}{c}\text { Persistent } \\
\text { dizziness }\end{array}$ & 0 & 4 & 5 & 26 \\
\hline $\begin{array}{l}1 \\
6\end{array}$ & $\mathrm{M}$ & $\begin{array}{l}6 \\
0\end{array}$ & $\mathrm{R}$ & $\begin{array}{c}19 \\
0\end{array}$ & $\mathrm{~N}$ & $\begin{array}{c}\text { yes, } \\
\text { iterative } \\
/ \\
\text { moderat } \\
\text { e } \\
\text { efficacy }\end{array}$ & $\begin{array}{c}\text { AIC } \\
\text { A }\end{array}$ & $\begin{array}{c}\text { partial } \\
\text { resolution }\end{array}$ & 22 & 0 & 5 & 1 & 6 & 2 \\
\hline
\end{tabular}




\begin{tabular}{|c|c|c|c|c|c|c|c|c|c|c|c|c|c|c|}
\hline $\begin{array}{l}1 \\
7\end{array}$ & $\mathrm{M}$ & $\begin{array}{l}5 \\
1\end{array}$ & $\mathrm{~L}$ & $\begin{array}{c}12 \\
1\end{array}$ & $\mathrm{~N}$ & $\begin{array}{c}\text { yes, } \\
\text { iterative } \\
/ \\
\text { moderat } \\
\text { e } \\
\text { efficacy } \\
\text { / FP, } \\
\text { ptosis }\end{array}$ & $\begin{array}{l}\mathrm{PIC} \\
\mathrm{A}+ \\
\mathrm{VA}\end{array}$ & $\begin{array}{c}\text { persistenc } \\
\mathrm{e}^{*}\end{array}$ & 16 & 0 & 9 & 5 & 17 & 8 \\
\hline $\begin{array}{l}1 \\
8\end{array}$ & $\mathrm{~F}$ & $\begin{array}{l}5 \\
2\end{array}$ & $\mathrm{~L}$ & 63 & $\mathrm{~N}$ & no & $\begin{array}{c}\text { PIC } \\
\text { A }\end{array}$ & $\begin{array}{c}\text { persistenc } \\
\mathrm{e}\end{array}$ & 13 & 0 & 7 & 7 & 23 & 21 \\
\hline $\begin{array}{l}1 \\
9\end{array}$ & $\mathrm{~F}$ & $\begin{array}{l}7 \\
2\end{array}$ & $\mathrm{~L}$ & $\begin{array}{c}13 \\
5\end{array}$ & $\mathrm{~N}$ & $\begin{array}{c}\text { yes, } \\
\text { iterative } \\
\text { / loss of } \\
\text { efficacy }\end{array}$ & $\begin{array}{c}\text { PIC } \\
\text { A }\end{array}$ & $\begin{array}{l}\text { immediate } \\
\text { complete } \\
\text { resolution }\end{array}$ & 13 & 0 & 23 & 0 & 83 & 8 \\
\hline $\begin{array}{l}2 \\
0\end{array}$ & $\mathrm{~F}$ & $\begin{array}{l}5 \\
2\end{array}$ & $\mathrm{~L}$ & 4 & $\mathrm{~N}$ & $\begin{array}{c}\text { yes, } 2 \\
\text { inj. / } \\
\text { moderat } \\
\text { e } \\
\text { efficacy }\end{array}$ & $\begin{array}{c}\text { PIC } \\
\text { A }\end{array}$ & $\begin{array}{l}\text { immediate } \\
\text { complete } \\
\text { resolution }\end{array}$ & 14 & $\begin{array}{c}\text { Hearing } \\
\text { loss }+ \\
\text { transient } \\
\text { dizziness } \\
\text { / healing }\end{array}$ & 20 & 4 & 66 & 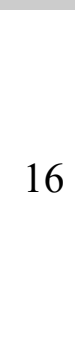 \\
\hline $\begin{array}{l}2 \\
1\end{array}$ & $\mathrm{M}$ & $\begin{array}{l}5 \\
5\end{array}$ & $\mathrm{~L}$ & 68 & $\mathrm{~N}$ & $\begin{array}{c}\text { yes, } \\
\text { iterative } \\
\text { moderat } \\
\text { e } \\
\text { efficacy }\end{array}$ & $\begin{array}{c}\text { PIC } \\
\text { A }+ \\
\text { VA } \\
+ \\
\text { AIC } \\
\text { A }\end{array}$ & $\begin{array}{l}\text { delayed } \\
\text { complete } \\
\text { resolution }\end{array}$ & 16 & 0 & 8 & 0 & 31 & 0 \\
\hline $\begin{array}{l}2 \\
2\end{array}$ & $\mathrm{M}$ & $\begin{array}{l}7 \\
4\end{array}$ & $\mathrm{R}$ & 58 & $\mathrm{~N}$ & no & $\begin{array}{c}\mathrm{PIC} \\
\mathrm{A}\end{array}$ & $\begin{array}{l}\text { immediate } \\
\text { complete } \\
\text { resolution }\end{array}$ & 12 & $\begin{array}{l}\text { transient } \\
\text { dizziness }\end{array}$ & $\begin{array}{l}\mathrm{N} \\
\mathrm{D}\end{array}$ & $\begin{array}{l}\mathrm{N} \\
\mathrm{D}\end{array}$ & ND & ND \\
\hline $\begin{array}{l}2 \\
3\end{array}$ & $\mathrm{~F}$ & $\begin{array}{l}7 \\
6\end{array}$ & $\mathrm{~L}$ & $\begin{array}{c}14 \\
5\end{array}$ & $\mathrm{~N}$ & no & $\begin{array}{l}\text { PIC } \\
\mathrm{A}+ \\
\text { VA }\end{array}$ & $\begin{array}{l}\text { immediate } \\
\text { complete } \\
\text { resolution }\end{array}$ & 12 & $\begin{array}{l}\text { CSF leak } \\
\text { / healing }\end{array}$ & $\begin{array}{l}\mathrm{N} \\
\mathrm{D}\end{array}$ & $\begin{array}{l}\mathrm{N} \\
\mathrm{D}\end{array}$ & ND & ND \\
\hline
\end{tabular}


Table 1. Clinical data, spasm results and questionnaire responses per patient after primary surgery. HFS-8 and HFS-30 scores out of 32 and 120, respectively. *: Patients \#5 and \#17 underwent revision surgery, with immediate complete resolution of spasm; impingement not released for patient $\# 7$.

Pt. = patient; $\mathrm{M}=$ male; $\mathrm{F}=$ female $\mathrm{L}=$ left; $\mathrm{R}=$ right; inj. = injection( $(\mathrm{s}) ; \mathrm{FP}=$ facial palsy; VA = vertebral artery; AICA = anteroinferior cerebellar artery; PICA $=$ posteroinferior cerebellar artery; pre $=$ preoperative; post $=$ postoperative, $\mathrm{ND}=$ no data. 


\section{Postoperative $(>1$}

\section{HFS-8}

Score per item (/4)

1. Had difficult driving

2. Had difficulty reading

3. Had difficulty watching television/movies

4. $\quad$ Felt depressed

5. Avoided eye contact

6. Felt embarrassed about having the condition

7. Felt worried about others' reaction to you

8. Sleep disturbance due to hemifacial spasm

Total score (/32)
Preoperative

media Q1-Q3 year)

IQ media Q1- IQ

$\mathrm{R} \quad \mathrm{n}$

Q3 R

$\begin{array}{lllllll}1 & 0-2 & 2 & 0 & 0-0 & 0 & <0.05\end{array}$

$\begin{array}{lllllll}1 & 0-2.5 & 2.5 & 0 & 0-1 & 1 & <0.05\end{array}$

$\begin{array}{lllllll}0 & 0-2 & 2 & 0 & 0-0 & 0 & <0.05\end{array}$

2

$\begin{array}{llllll}1-3 & 2 & 0 & 0 & 0 & < \\ & & & 0-0 & & 0.001\end{array}$

$\begin{array}{lllllc} & & & & & \\ 1-3.5 & & 0 & 0-1 & 1 & 0.001\end{array}$

$\begin{array}{lllllll} & 2 & 0 & & & 0.5 & \\ & 2-4 & & & 0-0.5 & & 0.001\end{array}$

2

$\begin{array}{llllll}1.5-4 & 2.5 & 0 & 0-1 & 1 & 0.001\end{array}$

$\begin{array}{lllllll}1 & 0-3.5 & 3.5 & 0 & 0-0 & 0 & <0.05\end{array}$

$16 \quad 8-20.5$

12.

$\begin{array}{llll}5 & 0.5 & 0-4.5 & 4.5\end{array}$

\section{Postoperative $(>1$}

$\underline{\text { Preoperative }}$

year)
Score per item $(/ 4)$

Mobility (/20)

1. Had difficulty doing leisure activities

2. Had difficulty looking after your home

3. Had difficulty at work

4. Had difficulty driving

5. Had difficulty crossing the road

Activities of daily living (/20)

6. Had difficulty reading

7. Had difficulty watching television/movies media

$\mathrm{n}$

6

1

0

2

2

0

4

1 $\begin{array}{lllllll}2 & 1-2.5 & 1.5 & 0 & 0-1 & 1 & <0.05\end{array}$

$$
\text { Q1-Q3 }
$$

IQ media Q1- IQ

$\mathrm{R} \quad \mathrm{n}$

2-11

$9 \quad 0$

$0-2.5 \quad 2.5 \quad 0$

$0-2.5 \quad 2.5 \quad 0$

$0-3.5 \quad 2.5 \quad 0$

$0-3 \quad 3 \quad 0$

$0-1.5 \quad 1.5 \quad 0$

$\begin{array}{lll}1.5-8 & 6.5 & 0\end{array}$

$\begin{array}{lllllll}2 & 1-2.5 & 1.5 & 0 & 0-1 & 1 & <0.05\end{array}$

$\begin{array}{lllll}0-2 & 2 & 0 & 0-0 & 0\end{array}$

Q3 R

$0-1 \quad 1<0.05$

$0-0 \quad 0<0.05$

$0-0 \quad 0<0.05$

$0-0 \quad 0<0.05$

$0-0 \quad 0<0.05$

$0-0 \quad 0 \quad$ ns

$0-2 \quad 2$

0.005 
8. Had difficulty using computer

9. Had difficulty writing

10. Had difficulty doing household chores

Emotional well-being (/28)

11. Felt depressed

12. Felt weepy and tearful

13. Felt angry or bitter

14. Felt anxious of going blind

15. Felt fearful of treatment

16. Felt worried of getting a stroke

17. Felt worried of losing your job

Stigma (/16)

18. Avoided eye contact

19. Avoided eating and drinking in public

20. Felt embarrassed about having the condition

21. Felt worried about others' reaction to you

$$
\text { Social support (/12) }
$$

22. Had problems with close relationship

Did not have support from your spouse or

23. partner

24. Did not have support from family or friends

$$
\text { Cognition (/12) }
$$

25. Had problems with concentration

26. Had problems with headaches

27. Had problems with giddiness

$\begin{array}{ccccccc}0 & 0-2 & 2 & 0 & 0-0 & 0 & <0.05 \\ 0 & 0-2 & 2 & 0 & 0-0 & 0 & <0.05 \\ 0 & 0-1.5 & 1.5 & 0 & 0-0 & 0 & <0.05\end{array}$

$11 \quad 6-13 \quad 7 \quad 0 \quad 0-3 \quad 3$

0.001

$\begin{array}{llllll}3 & 2-3 & 1 & 0 & 0-1 & 1\end{array}$

0.001

$2 \quad 0.5-3 \quad 2.5 \quad 0 \quad 0-1 \quad 1<0.05$

$3 \quad 0.5-3 \quad 2.5 \quad 0 \quad 0-0 \quad 0$ $<$

$\begin{array}{ccccccc}0 & 0-1 & 1 & 0 & 0-0 & 0 & <0.05 \\ 1 & 0-2.5 & 2.5 & 0 & 0-0 & 0 & <0.05 \\ 0 & 0-2 & 2 & 0 & 0-0 & 0 & \text { ns } \\ 0 & 0-1 & 1 & 0 & 0-0 & 0 & \text { ns }\end{array}$

9

$6.5-14.5 \quad 8 \quad 0 \quad 0-5 \quad 5$

0.005

$\begin{array}{llllllc}3 & 2-4 & 2 & 0 & 0-1 & 1 & < \\ & & & & & 0.001\end{array}$

$1 \quad 0-3 \quad 3 \quad 0 \quad 0-0 \quad 0 \quad<0.05$

$3 \quad 2.5-4 \quad 1.5 \quad 0 \quad 0-2 \quad 2$

0.001

$3 \quad 1.5-4 \quad 2.5 \quad 0 \quad 0-1 \quad 1$

$<$

$1 \quad 0-3.5 \quad 3.5 \quad 0 \quad 0-2 \quad 2 \quad$ ns

$\begin{array}{lllllll}0 & 0-1 & 1 & 0 & 0-0 & 0 & \text { ns }\end{array}$

$\begin{array}{lllllll}0 & 0-1 & 1 & 0 & 0-0.5 & 0.5 & \text { ns }\end{array}$

$\begin{array}{ccccccc}0 & 0-1 & 1 & 0 & 0-0 & 0 & \mathrm{~ns} \\ 3 & 1.5-6.5 & 5 & 0 & 0-2 & 2 & <0.05 \\ 2 & 0-3 & 3 & 0 & 0-0 & 0 & <0.05 \\ 1 & 0-3 & 3 & 0 & 0-1.5 & 1.5 & \mathrm{~ns} \\ 0 & 0-1.5 & 1.5 & 0 & 0-0.5 & 0.5 & \mathrm{~ns}\end{array}$


Communication (/12)

28. Had difficulty with speech

29. Felt unable to communicate properly

30. Felt ignored by people

Total score (/120) $\begin{array}{llllllc}< & 0.5-6 & 5.5 & 0 & 0-0 & 0 & 0.001\end{array}$

$\begin{array}{llllllc}2 & 0-3 & 3 & 0 & 0-0 & 0 & < \\ 0.005\end{array}$

$1 \quad 0-2 \quad 2 \quad 0 \quad 0-0 \quad 0 \quad<0.05$

$\begin{array}{lllllll}0 & 0-2 & 2 & 0 & 0-0 & 0 & <0.05\end{array}$

$\begin{array}{lllllll}38 & 23-61.5 & 38 . & 5 & 1-18.5 & \end{array}$ 5

Table 2. HFS- 8 and HFS-30 responses per item for the 19 respondent patients.

Pre- versus post-operative median values compared on non-parametric matched Wilcoxon test.

$\mathrm{Q} 1=1^{\text {st }}$ quartile; $\mathrm{Q} 3=3^{\text {rd }}$ quartile; $\mathrm{IQR}=$ interquartile range; $\mathrm{ns}=$ non-significant. 


\begin{tabular}{ccccc}
\hline & & right & left & $\mathrm{p}$ \\
\hline & $\mathrm{n}(\%)$ & $6(26.1)$ & $17(73.9)$ & \\
\hline $\begin{array}{c}\text { Multiple } \\
\text { vessels }\end{array}$ & $9(39.1)$ & 0 & $9(52.9)$ & $<0.05$ \\
\hline PICA & $10(43.5)$ & $3(50)$ & $7(41.2)$ & $\mathrm{ns}$ \\
\hline AICA & $2(8.7)$ & $2(33.3)$ & 0 & $<0.05$ \\
\hline VA & $2(8.7)$ & $1(16.7)$ & $1(5.9)$ & $\mathrm{ns}$ \\
\hline
\end{tabular}

Table 3. Causal vessels on intraoperative findings, according to spasm side. Significance assessed on chi $^{2}$ test.

$\mathrm{VA}=$ vertebral artery; AICA $=$ anteroinferior cerebellar artery; PICA = posteroinferior cerebellar artery; ns = non-significant. 
Figure 1. Intraoperative endoscopic views of microvascular decompression via a left retrosigmoid approach: release of a left vertebral artery triple impingement on trigeminal (V), facial (VII) and cochleovestibular (VIII) nerves. Symptomatology in patient \#2 comprised left trigeminal neuralgia, primary hemifacial spasm and tinnitus without hearing loss. Postoperatively, all symptoms immediately resolved completely.

1a. Before decompression: left vertebral artery (black star) compressing $\mathrm{V}$ (white arrow), VII and VIII (black arrow) nerves at emergence from brainstem.

1b. After decompression: Teflon fragments (white and black arrows) interposed between brainstem and left vertebral artery to protect V (white star), VII and VIII (black star) nerves' emergences.

Figure 2. Probability of complete resolution of hemifacial spasm after primary microvascular decompression: Kaplan-Meier estimation. Median recovery time: 15 days (dotted line).

*: Patients \#5 and \#17 underwent revision surgery at respectively 19 and 16 months, providing immediate complete resolution. 
Appendix 1a. HFS-8 quality of life questionnaire, adapted from Tan et al. [15]

\begin{tabular}{|l|l|l|l|}
\hline \multicolumn{1}{|c|}{ HFS-8 } & before surgery & after surgery (>1 year) \\
\hline 1. & Had difficulty drinving & & \\
\hline 2. & Had difficulty reading & \\
\hline 3. & Had difficulty watching television/movies & \\
\hline 4. & Felt depressed & \\
\hline 5. & Avoided eye contact & \\
\hline 6. & Felt embarrassed about having the condition & \\
\hline 7. & Felt worried about others' reaction to you & \\
\hline 8. & Sleep disturbance due to hemifacial spasm & & \\
\hline
\end{tabular}

The severity should be graded as follows: $0=$ normal; $1=$ slight disability; $2=$ moderate disability, no functional impairment; 3 = moderate disability, functional impairment; 4 = severely incapacitated.

Appendix 1b. Proposed French version of HFS-8 quality of life questionnaire.

\section{Questionnaire de Qualité de Vie HFS-8}

Merci de répondre à ce questionnaire en considérant tout d'abord votre état avant à la chirurgie puis votre état actuel (c'est-à-dire au moins 1 an après votre chirurgie) en utilisant l'échelle de cotation suivante :

- $0=$ normal ;

- 1 = gêne légère ;

- $\quad 2$ = gêne modérée, sans limitation fonctionnelle ;

- 3 = gêne modérée, avec limitation fonctionnelle ;

- 4 = gêne sévère.

1. Avez-vous eu des difficultés pour conduire?

2. Avez-vous eu des difficultés pour lire?

3. Avez-vous eu des difficultés pour regarder la télévision ou un film ?

4. Vous êtes-vous senti déprimé ?

5. Avez-vous évité le contact visuel ?

6. Vous êtes-vous senti gêné par votre état?

7. Avez-vous été inquiet de la réaction des autres à votre égard?

8. Avez-vous eu des troubles du sommeil à cause de votre spasme?

Appendix 2a. HFS-30 quality of life questionnaire, adapted from Tan et al. [14] 


\begin{tabular}{|c|c|c|c|}
\hline & HFS-30 & before surgery & after surgery (> 1 year) \\
\hline & Mobility & & \\
\hline 1. & Had difficulty doing leisure activities & & \\
\hline 2. & Had difficulty looking after your home & & \\
\hline 3. & Had difficulty at work & & \\
\hline 4. & Had difficulty drinving & & \\
\hline \multirow[t]{2}{*}{5.} & Had difficulty crossing the road & & \\
\hline & Activities of Daily Living & & \\
\hline 6. & Had difficulty reading & & \\
\hline 7. & Had difficulty watching television/movies & & \\
\hline 8. & Had difficulty using computer & & \\
\hline 9. & Had difficulty writing & & \\
\hline \multirow[t]{2}{*}{10.} & Had difficulty doing household chores & & \\
\hline & Emotional Well-Being & & \\
\hline 11. & Felt depressed & & \\
\hline 12. & Felt weepy and tearful & & \\
\hline 13. & Felt angry or bitter & & \\
\hline 14. & Felt anxious of going blind & & \\
\hline 15. & Felt fearful of treatment & & \\
\hline 16. & Felt worried of getting a stroke & & \\
\hline \multirow[t]{2}{*}{17.} & Felt worried of losing your job & & \\
\hline & Stigma & & \\
\hline 18. & Avoided eye contact & & \\
\hline 19. & Avoided eating and drinking in public & & \\
\hline 20. & Felt embarrassed about having the condition & & \\
\hline \multirow[t]{2}{*}{21.} & Felt worried about other's reaction to you & & \\
\hline & Social support & & \\
\hline 22. & Had problems with close relationship & & \\
\hline 23. & Did not have support from spouse or partner & & \\
\hline \multirow[t]{2}{*}{24.} & Did not have support from family or friends & & \\
\hline & Cognition & & \\
\hline 25. & Had problems with concentration & & \\
\hline 26. & Had problems with headaches & & \\
\hline \multirow[t]{2}{*}{27.} & Had problems with giddiness & & \\
\hline & Communication & & \\
\hline 28. & Had difficulty with speech & & \\
\hline 29. & Felt unable to communicate properly & & \\
\hline 30. & Felt ignored by people & & \\
\hline
\end{tabular}

The severity should be graded as follows: 0 = never; 1 = rarely; $2=$ sometimes; $3=$ often; $4=$ always.

Appendix 1b. Proposed French version of HFS-30 quality of life questionnaire. 


\section{Questionnaire de Qualité de Vie HFS-30}

Merci de répondre à ce questionnaire en considérant tout d'abord votre état avant à la chirurgie puis votre état actuel (c'est-à-dire au moins 1 an après votre chirurgie) en utilisant l'échelle de cotation suivante:

- $0=$ jamais ;

- 1 = rarement ;

- 2 = parfois ;

- 3 = souvent ;

- 4 = toujours.

1. Avez-vous eu des difficultés pour réaliser vos loisirs?

2. Avez-vous eu des difficultés pour entretenir votre maison?

3. Avez-vous eu des difficultés pour travailler?

4. Avez-vous eu des difficultés pour conduire?

5. Avez-vous eu des difficultés pour traverser la route? Activité de la vie quotidienne

6. Avez-vous eu des difficultés pour lire ?

7. Avez-vous eu des difficultés pour regarder la télévision ou un film ?

8. Avez-vous eu des difficultés pour utiliser votre ordinateur?

9. Avez-vous eu des difficultés pour écrire?

10. Avez-vous eu des difficultés pour accomplir des tâches ménagères? Bien-être émotionnel et psychique

11. Vous êtes-vous senti déprimé ?

12. Vous êtes-vous senti au bord des larmes ou avez pleuré ?

13. Vous êtes-vous senti en colère ou énervé ?

14. Avez-vous eu peur de devenir aveugle?

15. Avez-vous eu peur de vous faire soigner?

16. Avez-vous eu peur de faire un AVC?

17. Avez-vous eu peur de perdre votre travail? Stigmatisation / Dévalorisation

18. Avez-vous évité le contact visuel ?

19. Avez-vous évité de manger et boire en public?

20. Vous êtes-vous senti gêné par votre état?

21. Avez-vous été inquiet de la réaction des autres à votre égard?

Environnement social

22. Avez-vous eu des difficultés dans vos relations intimes?

23. Vous n'avez pas eu de soutien de votre conjoint?

24. Vous n'avez pas eu de soutien de votre famille ou de vos amis?

$$
\text { Cognition }
$$

25. Avez-vous eu des problèmes de concentration?

26. Avez-vous eu des problèmes de maux de tête?

27. Avez-vous eu des problèmes de vertiges? Communication

28. Avez-vous eu des difficultés pour parler?

29. Vous êtes-vous senti incapable de communiquer correctement?

30. Vous êtes-vous senti négligé / ignoré par les autres ? 


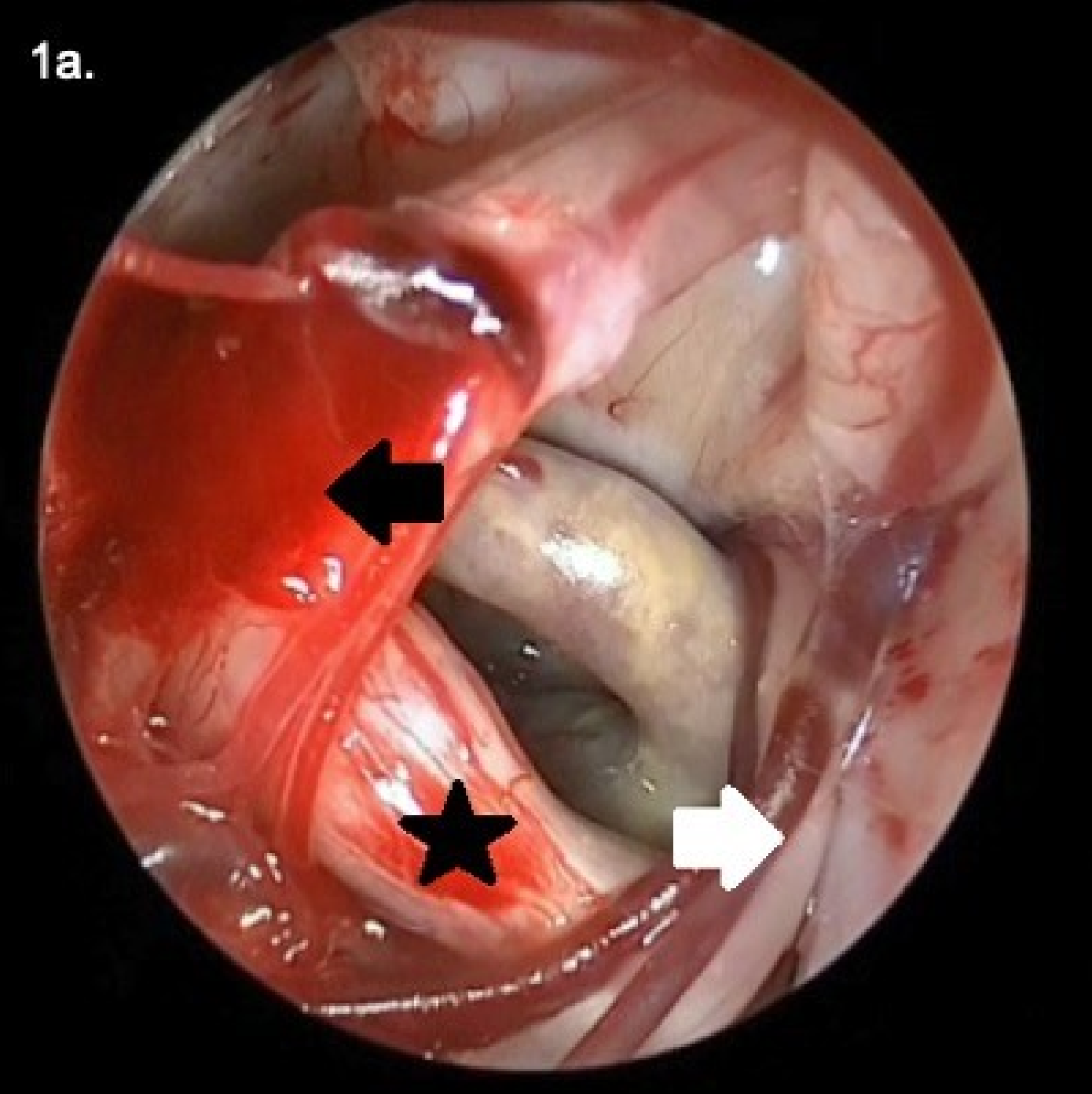

$1 b$. 